BIOFARM

Jurnal Ilmiah Pertanian

ISSN Print: 0216-5430; ISSN Online: 2301-6442

Vol. 15, No. 1, April 2019

\title{
Pengaruh Tingkat Kemasakan Benih dan Macam Media Tanam Terhadap Pertumbuhan Benih Karet (Hevea Brasiliensis L)
}

\author{
The Effect of Seed Levels and Types of Planting Media on the Growth of \\ Rubber Seed (Hevea brasiliensis L.)
}

\author{
Joko Santoso ${ }^{1 *}$ dan Ubad Badrudin² \\ ${ }^{1}$ PTPN IX Kebun Blimbing, Kabupaten Pekalongan, Jawa Tengah \\ ${ }^{2}$ Program Studi Agroteknologi, Fakultas Pertanian, Universitas Pekalongan \\ *Korespondensi Penulis: jok080800@gmail.com
}

\begin{abstract}
ABSTRAK
Tanaman karet merupakan salah satu komoditi pertanian yang penting, baik untuk lingkup internasional maupun Indonesia. Selain sebagai sumber devisa negara non-migas, karet juga menjadi sumber penghasilan hidup bagi banyak petani. Percobaan telah dilaksanakan di Desa Legokkalong Kecamatan Karanganyar Kabupaten Pekalongan. Rancangan Percobaan yang digunakan adalah RAK secara faktorial. Faktor pertama tingkat kemasakan benih (1 hari setelah jatuh dari pohon $=\mathrm{J} 1,3$ hari setelah jatuh dari pohon $=\mathrm{J} 2,6$ hari setelah jatuh dari pohon $=\mathrm{J} 3$ ), faktor kedua adalah macam media tanam $(\operatorname{tanah}=\mathrm{S} 1$, tanah + kompos $=\mathrm{S} 2$, tanah + humus $=\mathrm{S} 3$, tanah + pupuk kandang sapi $=\mathrm{S} 4)$. Variabel yang diamati meliputi kecepatan berkecambah, diameter batang, tinggi tanaman, jumlah daun, luas daun, panjang akar, berat basah tanaman, berat basah akar, berat kering tanaman dan berat kering akar. Data dianalisis menggunakan uji $F$ dan apabila berbeda nyata maka dilanjutkan dengan uji BNT 5\%, kemudian dilanjut dengan uji kontras ortogonal. Hasil penelitian menunjukkan bahwa tingkat kemasakan benih berbeda sangat nyata pada variabel diameter batang dan jumlah daun, berbeda nyata pada variabel tinggi tanaman, sedangkan pada variabel lainnya berbeda tidak nyata. Tingkat kemasakan benih terbaik adalah 6 hari setelah jatuh dari pohon. Macam media tanam berbeda sangat nyata terhadap luas daun, panjang akar dan berbeda nyata pada variabel berat kering akar serta berbeda tidak nyata pada variabel lainnya. Macam media tanam terbaik adalah tanah + pupuk kandang sapi (S4). Tidak terdapat interaksi antara tingkat kemasakan benih dan macam media tanam pada semua variabel.
\end{abstract}

Kata kunci : Karet, devisa, non migas, tingkat kemasakan benih, media tanam

\section{ABSTRACT}

Rubber plant is one of the important agricultural commodities, both internationally and in Indonesia. Apart from being a source of foreign exchange for non-oil and gas countries, rubber is a source of living income for many farmers. The experiment was conducted in Legokkalong Village, Karanganyar Subdistrict, Pekalongan Regency. The design was experiment as Randomized Block Design (RBD) in factorial. The first factor is the level of seed maturity (1 day after falling from the tree $=J 1,3$ days after falling from the tree $=J 2,6$ days after falling from the tree $=J 3$ ), the second factors are the type of planting media (soil $=S 1$, soil + compost $=S 2$, soil + humus $=S 3$, soil + cow manure $=S 4$ ). Variable analyzed were speed of germination, diameter of stem, height of plant, number of leafes, area of leafes, length of root, wet weight of plant, wet weight of root, dry weight of plant and dry weight of root. The date were analyzed by $F$ test and continued with Least Significance Different (LSD) level $5 \%$ if the result was significant different, then continued with orthogonal contrast test. The results showed that the level of seed maturity was very significant different in the variables diameter of stem and number of leaves, significant different in height of plant, whereas in other variables it was not significant different. The best level of seed maturity is 6 days after falling from the tree. Different types of planting media differ significant on area of leafes, length of root and significant different on dry weight of root and differ not significant in other variables. The best type of planting media is soil + cow manure (S4). There is no interaction between the level of seed maturity and the type of planting media on all variables.

Keywords: Rubber, foreign exchange, non oil and gas, seed maturity level, planting media

\section{PENDAHULUAN}

Komoditas perkebunan berkontribusi positif di Indonesia diantaranya adalah karet (Havea brasiliensis L), karena menjadi sumber pendapatan dan kesejahteraan masyarakat serta penggerak kemajuan ekonomi dan menjadi pusat-pusat baru disekitar perkebunan karet, selain itu karet juga berkontribusi yang nyata sebagai salah satu sumber devisa negara dengan total 25$40 \%$ dari total ekspor produk perkebunan (Purnomowati dkk., 2015). Sementara ini produksi karet di Indonesia pada tahun 2017 sebanyak 3.774.365 ton (Direktorat Jenderal 
Perkebunan, 2017), sedangkan kebutuhan karet dunia diperkirakan pada tahun 2020 akan mengalami peningkatan sebesar $2.6 \%$ per tahun (Kasman, 2009) dan pada tahun 2035 diperkirakan permintaan karet sebanyak 31.3 juta ton (Damanik, 2012). Melihat kondisi seperti ini maka harus dilakukan upaya untuk selalu meningkatkan produksinya. Rendahnya produksi karet disebabkan diantaranya adalah ketersediaan benih terbatas, terutama bagi perkebunan rakyat. Hal ini ditunjukkan dengan penggunaan benih asalan atau benih tidak unggul oleh pekebun, sehingga secara nyata mendorong pengembangan usaha perbenihan oleh penangkar (Sipayung dan Lasminingsih, 2012).

Menurut Ariyantoro (2006) benih merupakan unsur yang sangat penting dalam usaha produksi tanaman pertanian. Meskipun sarana produksi lainya terpenuhi, seperti unsur hara, air, dan cahaya. Apabila benih kurang baik maka hasilnya tidak maksimal. Hasil tanaman akan maksimal bila sarana produksi yang diperlukan terpenuhi dan benih yang digunakan berkualitas.

Biji karet segar memiliki daya kecambah yang baik dan ini didapatkan dari biji yang baru jatuh atau paling lama empat hari setelah rontok dari pohon. Tidak direkomendasikan biji dari hasil pengumpulan hari pertama digunakan karena waktu rontoknya biji tidak diketahui. Kolektivitas biji pada hari pertama dimungkinkan biji-biji tersebut telah terpapar beberapa minggu atau bahkan beberapa bulan sebelumnya, sehingga kondisinya sudah tidak segar lagi (Damanik dkk., 2010).

Viabilitas biji karet sangat erat hubunganya dengan tingkat kematangan biji. Masak fisiologis biji karet didapatkan pada saat berat segar biji maksimum atau berat kering dan kadar airnya tidak mengalami perubahan lagi. Daya kecambah dari biji yang masak fisiologis mencapai 97$100 \%$. Biji yang tepat untuk dipanen ialah ketika masak fisiologis yang dapat dilakukan secara manual dengan mengambil buah dari pohon. Kondisi tersebut, tingkat kematangan benih dan bobot keringnya maksimum. Kegiatan seperti ini tidak memungkinkan untuk dilakukan pada skala besar disamping pengerjaannya tidak mudah juga tidak menguntungkan (Boerhendhy, 2009).

Banyak hal yang harus dipenuhi dalam proses menumbuhkan tanaman sebagai persyaratan terkait dengan tingkat kebutuhan tanaman yang berbeda menurut jenisnya. Faktor penting yang harus diperhatikan dalam budidaya tanaman diantaranya adalah media tanam dan juga faktor iklim. Pertumbuhan tanaman sangat dipengaruhi oleh kondisi media tanam (Lestariningsih, 2012).

Media tanam merupakan instrumen penting untuk budidaya tanaman (Roni, 2015). Penggunaan media tanam disesuaikan dengan jenis tanaman yang akan dikembangkan. Menurut Lestariningsih (2012) tekstur yang gembur merupakan kondisi yang baik sebagai media tanam, karena perkembangan akar tanaman menjadi mudah. Media seperti ini biasanya ditunjukkan sebagai hasil dari peggunaan bahan organik dengan pemberian kompos, humus, atau pupuk kandang. Disamping itu, Shara dkk., (2014) menyatakan bahwa media yang memiliki kemampuan untuk menyediakan air dan unsur hara dalam jumlah yang cukup akan mendukung proses pertumbuhan bibit.

Tujuan dilakukan penelitian ini adalah untuk mengetahui tingkat kemasakan benih, jenis media tanam yang tepat dan interaksinya untuk meningkatkan partumbuhan biji tanaman karet.

\section{BAHAN DAN METODE}

Percobaan telah dilaksanakan di Desa Legokkalong Kecamatan Karanganyar Kabupaten Pekalongan pada ketinggian tempat \pm 110 meter di atas permukaan laut (mdpl) dengan jenis tanah Latosol. Percobaan dilaksanakan selama 3 bulan, yaitu mulai bulan Mei sampai dengan Agustus 2018.

Bahan yang digunakan dalam percobaan ini adalah biji karet klon BPM 24, polybag, tanah, pasir, kompos, humus, pupuk kandang sapi bambu, plastik, tali rafia fungisida. Alat yang digunakan dalam percobaan ini adalah cangkul, sabit, papan nama, label, alat tulis, meteran, timbangan analitik, gembor, ember.

Percobaan disusun secara faktorial dengan menggunakan Rancangan Acak Kelompok (RAK) yang diulang tiga kali. Faktor pertama adalah tingkat kemasakan benih yang terdiri dari 3 taraf yaitu 1 hari setelah jatuh dari pohon, 3 hari setelah jatuh dari pohon dan 6 hari setelah jatuh dari pohon. Faktor kedua adalah macam media tanam terdiri atas 3 taraf yaitu Tanah, tanah + kompos, tanah + humus dan tanah + pupuk kandang sapi. Kombinasi perlakuan ada 12 dan masing-masing diulang tiga kali sehingga terdapat 36 satuan percobaan.

Variabel yang diamati kecepatan berkecambah, diameter batang, tinggi tanaman, jumlah daun, luas daun, panjang akar, berat 
basah tanaman, berat basah akar, berat kering tanaman dan berat kering akar. Data dianalisis dengan uji $\mathrm{F}$ dan apabila terdapat perbedaan antara faktor yang dicoba, maka analisis dilanjutkan dengan uji BNT, kemudian dilanjut dengan uji kontras orthogonal.

\section{HASIL DAN PEMBAHASAN \\ Kemasakan Benih}

Hasil penelitian menunjukkan bahwa tingkat kemasakan benih berbeda sangat nyata terhadap diameter batang, jumlah daun dan berbeda nyata terhadap tinggi tanaman.
Diameter batang, jumlah daun dan tinggi tanaman tertinggi dicapai pada tingkat kemasakan benih 6 hari setelah jatuh dari pohon, diikuti 3 hari setelah jatuh dari pohon, dan paling rendah 1 hari setelah jatuh dari pohon. Hal ini disebabkan karena tingkat kemasakan benih 6 hari setelah jatuh dari pohon benar-benar matang secara fisiologis. Masak fisiologis benih yang baik berpengaruh positif terhadap tingkat viabilitas benih, namun apabila kondisi demikian tidak terpenuhi, maka beberapa jenis tanaman menunjukkan kondisi yang tidak berkecambah.

Tabel 1. Angka Rata-Rata dan Hasil Analisis Statistik Pada Fase Pertumbuhan Benih Karet

\begin{tabular}{lccccc}
\hline \multicolumn{1}{c}{ Perlakuan } & $\begin{array}{c}\text { Kecepatan } \\
\text { Berkecambah } \\
\text { (hari) }\end{array}$ & $\begin{array}{c}\text { Diameter } \\
\text { Batang } \\
(\mathrm{mm})\end{array}$ & $\begin{array}{c}\text { Tinggi } \\
\text { Tanaman } \\
(\mathrm{cm})\end{array}$ & $\begin{array}{c}\text { Jumlah } \\
\text { Daun } \\
\text { (helai) }\end{array}$ & $\begin{array}{c}\text { Luas Daun } \\
\left(\mathrm{cm}^{2}\right)\end{array}$ \\
\hline $\begin{array}{l}\text { Tingkat Kemasakan benih } \\
\text { J1 }\end{array}$ & 3,16 & $0,41 \mathrm{a}$ & $29,40 \mathrm{a}$ & $18,35 \mathrm{a}$ & 55,64 \\
J2 & 2,83 & $0,45 \mathrm{~b}$ & $31,47 \mathrm{a}$ & $18,50 \mathrm{a}$ & 58,76 \\
J3 & 3,03 & $0,49 \mathrm{c}$ & $35,96 \mathrm{a}$ & $23,10 \mathrm{~b}$ & 62,54 \\
\hline Macam Media Tanam & & & & & \\
\hline S1 & 3,41 & 0,44 & 32,97 & 18,76 & $61,43 \mathrm{a}$ \\
S2 & 2,83 & 0,43 & 30,24 & 20,00 & $51,34 \mathrm{a}$ \\
S3 & 2,86 & 0,46 & 33,18 & 21,16 & $51,04 \mathrm{a}$ \\
S4 & 2,93 & 0,46 & 32,71 & 20,02 & $72,11 \mathrm{~b}$ \\
\hline
\end{tabular}

Keterangan : Angka yang diikuti huruf yang sama pada kolom dan baris menunjukkan tidak berbeda nyata menurut uji BNT taraf $5 \%$

Daya kecambah biji karet sangat erat hubungannya dengan tingkat kemasakan biji. Biji karet dikatakan masak fisiologis pada saat berat segar biji maksimum atau pada saat tidak ada lagi pertambahan berat kering dan kadar airnya sudah konstan. Biji yang dipanen pada saat masak fisiologis mempunyai daya kecambah $97-100 \%$. Bila buah sudah masak, maka akan pecah dengan sendirinya menurut ruanganruangannya dan setiap pecahan akan tumbuh menjadi individu baru jika jatuh ke tempat yang tepat (Prasetya, 1997).

Menurut Rusmin dan Darwati (2018) tingkat kemasakan benih saat panen mempengaruhi viabilitas benih. Benih yang dipanen sebelum masak atau terlanjur masak mempengaruhi kualitas benih menjadi rendah, hal ini bisa dilihat dari kerusakan secara fisik seperti retak-retak, mengkerut dan gangguan fisiologi.

\section{Macam Media Tanam}

Berdasarkan hasil analisis statistik perlakuan macam media tanam berbeda sangat nyata terhadap luas daun dan panjang akar. Luas daun terluas dicapai pada media tanam tanah + pupuk kandang sapi (S4), diikuti tanah (S1), dan tanah + kompos (S2), sedangkan terkecil pada media tanam tanah + humus (S3). Hal ini karena media tanam tanah + pupuk kandang sapi mengandung unsur $\mathrm{N}, \mathrm{P}, \mathrm{K}$ yang cukup bagi pertumbuhan tanaman. Ketersediaan unsur hara seperti nitrogen, fosfor dan kalium mempengaruhi pembentukan luas daun. Menurut Lingga dan Marsono (2004) pertumbuhan vegetatif tanaman terutama daun, pertambahan tunas, dan tinggi tanaman ditopang oleh ketersediaan nitrogen. 
Tabel 2. Angka rata-rata dan Analisis Statistik pada Stadia Vegetatif Benih Karet

\begin{tabular}{lccccc}
\hline \multicolumn{1}{c}{ Perlakuan } & $\begin{array}{c}\text { Panjang } \\
\text { Akar (cm) }\end{array}$ & $\begin{array}{c}\text { Berat Basah } \\
\text { Tanaman } \\
\text { (gram) }\end{array}$ & $\begin{array}{c}\text { Berat Basah } \\
\text { Akar (gram) }\end{array}$ & $\begin{array}{c}\text { Berat Kering } \\
\text { Tanaman } \\
\text { (gram) }\end{array}$ & $\begin{array}{c}\text { Berat } \\
\text { Kering Akar } \\
\text { (gram) }\end{array}$ \\
\hline Tingkat Kemasakan benih & & & & & \\
J1 & 17,89 & 22,76 & 5,26 & 7,56 & 1,26 \\
J2 & 18,79 & 23,95 & 5,24 & 8,59 & 1,47 \\
J3 & 17,72 & 26,49 & 5,94 & 9,51 & 1,50 \\
\hline Macam Media Tanam & & & & & \\
\hline S1 & $19,15 \mathrm{~b}$ & 22,86 & 5,69 & 8,80 & $1,73 \mathrm{~b}$ \\
S2 & $20,07 \mathrm{c}$ & 23,47 & 5,07 & 7,72 & $1,19 \mathrm{a}$ \\
S3 & $18,04 \mathrm{~b}$ & 24,58 & 5,39 & 8,67 & $1,43 \mathrm{a}$ \\
S4 & $15,28 \mathrm{a}$ & 26,70 & 5,79 & 9,02 & $1,28 \mathrm{a}$ \\
\hline Keterangan : Angka yang dikuti huruf yang sama pada kolom dan baris menunjukkan tidak berbeda nyata menurut uji BNT \\
\multicolumn{4}{c}{ taraf 5\% }
\end{tabular}

Menurut Wijayanti (2010) nitrogen berperan dalam mendorong pertumbuhan vegetatif, sedangkan unsur fosfat diperlukan tanaman sebagai pengatur dan mendorong pertumbuhan akar, sehingga tanaman dapat tumbuh tegak, kokoh dan kemampuan akar dalam menyerap air lebih besar. Ketersedian unsur hara $\mathrm{N}$ berpengaruh terhadap pembelahan sel sehingga laju fotosintesis yang tinggi mampu mempengaruhi partumbuhan dan perkembangan panjang akar tanaman.

Berdasar hasil penelitian menunjukkan bahwa macam media tanam berbeda nyata terhadap berat kering akar. Berat kering akar terberat dicapai pada macam media tanam tanah (S1), diikuti macam media tanam tanah + humus (S3), dan macam media tanam tanah + pupuk kandang sapi, sedangkan

berat akar terendah terendah pada macam media tanam tanah + kompos (S2). Hal ini disebabkan karena media tanah mampu menahan air lebih besar dibandingkan dengan media tanam lainnya. Air dibutuhkan tanaman untuk proses fotosintesis sehingga ketersediaan air dapat mempengaruhi pertumbuhan dan perkembangan akar.

Menurut Hardjowigeno (1992) tanah dapat menyimpan air terjadi karena diserap oleh massa tanah, tertahan oleh lapisan kedap air, dan keadaan drainase yang kurang baik. Disamping itu, juga adanya gaya adhesi, kohesi, dan gravitasi menyebabkan air dapat meresap atau ditahan oleh tanah.
Berat basah dan berat kering akar dipengaruhi oleh banyaknya kandungan karbohidrat maupun protein yang dihasilkan dari proses metabolisme tanaman, makin banyak karbohidrat dan protein yang ditranslokasikan ke akar, akan meningkatkan berat basah dan berat kering akar.

\section{Interaksi antara Tingkat Kemasakan Benih dan Macam Media Tanam}

Hasil penelitian menunjukkan bahwa interaksi antara tingkat kemasakan benih dan macam media tanam berbeda tidak nyata terhadap semua variabel yang diamati. Hal ini karena tingkat kemasakan benih dan macam media tanam tidak saling mempengaruhi. Macam media tanam semuanya mengandung tanah dengan proporsi yang lebih banyak, sehingga memberikan pengaruh yang sama, sedangkan benih yang digunakan memiliki cadangan makanan yang relatif sama, sehingga pertumbuhannya relatif sama.

Dwidjoseputro (1984) menyatakan bahwa benih akan berkecambah dan tumbuh baik apabila proses imbibisi dan ketersediaan cadangan makanan tercukupi. Qomara (2003), menyatakan bahwa kecepatan tumbuh benih karet sangat dipengaruhi oleh faktor ketersediaan makanan yang terdapat dalam biji dalam jumlah yang cukup, sehingga dapat mendorong pertumbuhan benih. Pramana, (2010) menambahkan bahwa media tanam yang baik berisikan zat hara yang diperlukan oleh tanaman. 


\section{SIMPULAN}

1. Tingkat kemasakan benih berbeda sangat nyata pada variabel diameter batang dan jumlah daun, berbeda nyata pada variabel tinggi tanaman, sedangkan pada variabel lainnya berbeda tidak nyata. Tingkat kemasakan benih terbaik untuk pertumbuhan biji karet adalah 6 hari setelah jatuh dari pohon.

2. Macam media tanam berbeda sangat nyata terhadap luas daun, panjang akar dan berbeda nyata pada variabel berat kering akar serta berbeda tidak nyata pada variabel lainnya. Macam media tanam terbaik untuk pertumbuhan biji karet adalah tanah + pupuk kandang sapi (S4).

3. Tidak terdapat interaksi antara tingkat kemasakan benih dan macam media tanam pada semua variabel.

\section{DAFTAR PUSTAKA}

Ariyantoro, H. 2006. Teknik Perbanyakan Tanaman. Citra Aji Paramana, Yogyakarta.

Boerhendhy, I. 2009. Pengelolaan Biji Karet untuk Bibit. Warta Penelitian dan Pengembangan Pertanian. 31(5):1-9.

Damanik, S. 2012. Pengembangan Karet (Havea brasiliensis) Berkelanjutan Di Indonesia. Perspektif. 11 (1): 91 102.

Damanik, S., Syakir, M., Made,T., dan Siswanto. 2010. Budidaya Pasca Panen Karet. Pusat Penelitian dan Perkebunan. Bogor.

Direktorat Jenderal Perkebunan. 2017. Karet; Statistik Perkebunan Indonesia 2016-2018. Kementerian Pertanian.

Dwidjoseputro, D. 1984. Pengantar Fisiologi Tumbuhan. Gramedia. Jakarta

Hardjowigeno, S. 1992. Illmu Tanah. Mediyatama Sarana Perkasa. Jakarta.

Kasman. 2009. Pengembangan Perkebunan Karet dalam Usaha Peningkatan Ekonomi Daerah dan Pendapatan
Petani di Provinsi Aceh. Jurnal Ekonomi Pembangunan. 10(2): $250-266$.

Lestariningsih, A. 2012. Meramu Media Tanam Untuk Pembibitan. Cahaya Atma Pustaka, Yogyakarta.

Lingga $P$ dan Marsono. 2004. Petunjuk penggunaan pupuk. Penebar Sawadaya. Jakarta.

Pramana, G. 2010. Manajemen Pembibitan dan Penanaman Kelapa Sawit. Diakses melalui http://www.deptan.go.id pada tanggal 10 November 2013.

Prasetya, S.H. 1997. Teknik Usaha Mempercepat Masa Tanaman Belum

Menghasilkan (TBM) Tanaman Karet. Buletin Penalaran Mahasiswa. 3(1):815.

Qomara, W. 2003. Pengantar Produksi Benih. Fakultas Pertanian IPB. Bogor

Roni, N.G.K. 2015. Bahan Ajar: Tanah Sebagai Media Tumbuh. Fakultas Peternakan, Universitas Udayana, Bali.

Rusmin, D dan I. Darwati. 2018. Studi Fenologi Dan Penentuan Masak Fisiologis Benih Purwoceng. Jurnal Agronida. 1 (1): 45-54.

Sipayung, H. H. dan M. Lasminingsih. 2012. Petunjuk Praktis Pembibitan Karet. Agromedia Pustaka, Jakarta.

Shara, D., M. Izzati, E. Prihastanti. 2014. Perkecambahan Biji Dan Pertumbuhan Bibit Batang Bawah Karet (Havea brasiliensis Muell Arg.) Dari Klon Dan Media Yang Berbeda. Jurnal Biologi. 3 (3):60-74.

Wijayanti, P. 2010. Budidaya Tanaman Obat Rosella Merah (Hibiscus sabdariffa L.) dan Pemanfaatan Senyawa Metabolis Sekundernya di PT. Temu Kencono, Semarang. Jurusan Agribisnis Agrofarmaka. Universitas Sebelas Maret 